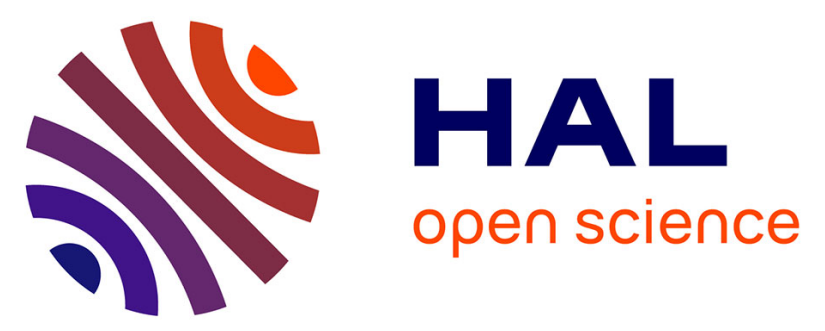

\title{
Preliminary investigation of multi-biomarker responses in three-spined stickleback (Gasterosteus aculeatus L.) sampled in contaminated streams
}

Wilfried Sanchez, Selim Ait-Aissa, Olivier Palluel, Jean-Maxence Ditche, Jean-Marc Porcher

\section{To cite this version:}

Wilfried Sanchez, Selim Ait-Aissa, Olivier Palluel, Jean-Maxence Ditche, Jean-Marc Porcher. Preliminary investigation of multi-biomarker responses in three-spined stickleback (Gasterosteus aculeatus L.) sampled in contaminated streams. Ecotoxicology, 2007, 16 (2), pp.279-287. 10.1007/s10646-0060131-z . ineris-00961909

HAL Id: ineris-00961909

https://hal-ineris.archives-ouvertes.fr/ineris-00961909

Submitted on 20 Mar 2014

HAL is a multi-disciplinary open access archive for the deposit and dissemination of scientific research documents, whether they are published or not. The documents may come from teaching and research institutions in France or abroad, or from public or private research centers.
L'archive ouverte pluridisciplinaire HAL, est destinée au dépôt et à la diffusion de documents scientifiques de niveau recherche, publiés ou non, émanant des établissements d'enseignement et de recherche français ou étrangers, des laboratoires publics ou privés. 
Preliminary investigation of multi-biomarker responses in three-spined stickleback (Gasterosteus aculeatus $\mathbf{L}$.) sampled in contaminated streams

Wilfried Sanchez ${ }^{1 *}$, Sélim Aït-Aïssa ${ }^{1}$, Olivier Palluel ${ }^{1}$ Jean-Maxence Ditche $^{2}$ and Jean-Marc Porcher $^{1}$

${ }^{1}$ Institut National de l'Environnement Industriel et des Risques (INERIS), Unité d'Evaluation des Risques Ecotoxicologiques, BP2, 60550, Verneuil-en-Halatte, France

${ }^{2}$ Conseil Supérieur de la Pêche, Délégation régionale $N^{\circ} 1,60200$ Compiègne, France

\footnotetext{
* Corresponding author. Tel : +33 (0)3 44556942 ; Fax: +33 (0)3 44556767

E-mail address : Wilfried.Sanchez@ineris.fr (W. Sanchez)
} 


\section{ABSTRACT}

Recently, the three-spined stickleback (Gasterosteus aculeatus L.) has been proposed as a suitable fish species for detecting both androgen- and estrogen-induced endocrine disruption by environmental pollutants. This relatively pollution-tolerant fish is present in most European streams and small rivers but also coastal and estuarian areas. The purpose of the present field study was to determine the extent to which multiple biomarkers in this fish species could distinguish between streams with different pollution levels. Sticklebacks were sampled in French rivers characterised by various urban, industrial or agricultural contaminations and in outdoor lotic mesocosms as reference site. Physiological parameters including condition factor and liver somatic index, biotransformation enzymes such as 7ethoxyresorufin-O-deethylase (EROD) and glutathione-S-transferase, antioxidant enzymes including glutathione peroxidase and total glutathione (GSH) content and lipoperoxidation (as TBARS) showed several differences between sites. For example, fish from an heavily contaminated stream exhibited a 9-fold EROD induction associated to a decrease of GSH and a 3-fold increase of TBARS content in comparison to fish from uncontaminated sites. When fish were tranferred from polluted river to clean water, some of these biomarkers rapidly returned to basal levels found in fish in the reference site while others, like TBARS levels were still high after 2 weeks of depuration. Based on multivariate analyses, the battery of biomarkers proved to differentiate all sites, with a very good classification rate for highly contaminated streams. Influence of fish gender and sampling period on biomarker responses was also observed and is discussed. The results of this field study provide additional support for the use of stickleback for in situ multi-biomarker assessment.

Keywords : three-spined stickleback ; biomarkers ; oxidative stress ; field study ; depuration experiment. 


\section{INTRODUCTION}

Biomarkers have been proposed as sensitive tools for detecting environmental exposure and adverse effects of toxic anthropogenic chemicals on aquatic organisms. Biomarkers have been defined as a change in biological response which can be related to exposure or toxic effect of environmental chemicals (Peakall, 1994). In recent years, the usefulness of a set of biomarkers has been demonstrated in environmental biomonitoring in several aquatic species, including freshwater fish (Galloway et al., 2004; Triebskorn et al., 2001). In European rivers, the fish species mostly employed to assess biological effects of contaminants using a set of biomarkers are chub and roach (Flammarion et al., 2002). However, due to the fish species diversity encountered in streams and estuaries, the assessment of various other species for biomarker-based biomonitoring is still needed. The three-spined stickleback (Gasterosteus aculeatus L.) appears to be a promising species to assess the impact of contaminants in aquatic biota in that it is relatively tolerant to environmental pollution, and that it inhabits most streams, small rivers, estuarian and coastal areas in Europe (Wootton, 1984). Moreover, this fish species is a well-studied model for biologists since behaviour, ecology and evolution of stickleback have been extensively characterised. The responses of several biochemical parameters such as vitellogenin (Pottinger et al., 2002), spiggin (Katsiadaki et al., 2002) and 7-ethoxyresorufin-O-deethylase (Holm et al., 1993) have been investigated in laboratory studies and have appeared as promising biomarkers of chemical exposure to be used in environmental biomonitoring. Despite its relative ubiquity, to our knowledge, cholinesterase activity and liver histopathology are the only biomarkers investigated and validated in the stickleback (Handy et al., 2002; Sturm et al., 2000) and, therefore efforts are still needed to validate other biochemical biomarker responses in situ for the monitoring of fish health in freshwater ecosystems.

In previous studies, we examined a set of hepatic biotransformation and oxidative stress endpoints as potential biomarkers for various pollutants in stickleback (Sanchez et al., 2006; Sanchez et al., 
2005). The purpose of the study was to validate these biomarkers in the field when this fish species are exposed to a variety of pollutants in rivers situated in Northern France. Biomarker responses in wild sticklebacks sampled in five sites subjected to different types and levels of contamination (Table I) were examined. The studied biomarkers were related to xenobiotic metabolism (i.e. 7 ethoxyresorufin-O-deethylase [EROD] and glutathione-S-transferase [GST]) and to oxidative stress (i.e. glutathione peroxidase [GPx], total glutathione content [GSH] and lipoperoxidation [TBARS]), as well as to physiological parameters (i.e. liver somatic index [HSI] and condition factor [CF]). Moreover, a first evaluation of biomarker reversibility in stickleback from one of the most contaminated streams was performed to investigate the evolution of biomarker profiles over a 15 day depuration period in clean water.

\section{MATERIALS AND METHODS}

\section{Sampling design}

During 2003 and 2004, five sites located in the North of France characterised by the presence of wild stickleback population and exhibiting various qualitative and quantitative contaminations were investigated. Table I summarises some general characteristics of the selected sites and fish sampling in each site. All sampling of adult sticklebacks were carried out by electrofishing in Spring (between June-July) and/or Autumn (September-October). All sampling sites have been impacted by urban and/or agricultural activities as determined by the Fish Based-Index (FBI) quality score based on occurrence and abundance data and reflecting the level of degradation of fish assemblage structure (Oberdorff et al., 2002). Therefore they could not be considered true reference sites so, reference fish were sampled at equivalent sampling periods in uncontaminated outdoor lotic mesocosms located at INERIS (Verneuil en Halatte, France). Each mesocosm channel was $20 \mathrm{~m}$ long, $1 \mathrm{~m}$ wide with a water depth of $0.3 \mathrm{~m}$ in the upper section and $0.7 \mathrm{~m}$ in the lower section. The mesocosms were initially set-up with natural and artificial sediments, aquatic plants, phytoplankton, periphyton, benthic and pelagic invertebrates, microorganisms and one fish species that is the 
stickleback. The channels were fed by denitrated water from a drinking water treatment plant with a flow of 800 l/h by channel.

\section{Depuration experiment}

To determine the potential reversibility of biomarkers when fish are returned to clean water, we collected 45 fish from the Réveillon (REV) river in Spring 2003 campaign and transferred them to the laboratory in aerated tanks. The fish were divided into three groups of 15 and placed in denitrated water (alkalinity, $367 \mathrm{mg} / \mathrm{L}$ as $\mathrm{CaCO}_{3} ; \mathrm{pH}, 8.35 \pm 0.05$ ) for periods of 4,8 and 15 days. This experiment was carried out in semi-static conditions with complete water renewal and food supply every 2 days. The water temperature was $14^{\circ} \mathrm{C} \pm 0.5^{\circ} \mathrm{C}$ and the photoperiod corresponded to natural light/dark cycle at this period.

\section{Sample preparation}

Fish were measured, weighed and sacrificed immediately after being caught. The CF was calculated according to Pottinger et al. (2002), while HSI was calculated as (liver weight / fish weight) x 100 . Livers were removed, weighed and frozen in liquid nitrogen prior to homogenisation and biochemical analysis. The homogenisation was in $200 \mu \mathrm{L}$ of ice-cold phosphate buffer (100 mM, $\mathrm{pH}$ 7.8) with $20 \%$ glycerol and $0.2 \mathrm{mM}$ phenylmethylsulfonyl fluoride using a Potter-Elvehjem homogeniser. The homogenates were centrifuged at $10,000 \mathrm{x} \mathrm{g}, 4^{\circ} \mathrm{C}$, for $15 \mathrm{~min}$ and the postmitochondrial fractions were used for biochemical assays. Total protein concentrations were determined using bovine serum albumin (Sigma-Aldrich Chemicals, France) as a standard (Bradford, 1976).

\section{Biochemical biomarker assays}

EROD, GST, GPx and GSH assays were conducted respectively according to the methods of Flammarion et al. (1998), Habig et al. (1974), Paglia and Valentine (1967) and Vandeputte et al. (1994). These assays were adapted in microplates and optimised for stickleback to fit the linearity of each assay. The total protein concentrations used for each assay were 0.5 to $10 \mathrm{~g} / \mathrm{L}$ for EROD 
and $0.5,5$ and $4 \mathrm{~g} / \mathrm{L}$ for GST, GPx and GSH, respectively. Lipid peroxidation was estimated by adding $345 \mu \mathrm{L}$ of TBARS reagent (Ohkawa et al., 1979) to $60 \mu \mathrm{L}$ of a $3 \mathrm{~g}$ proteins/L diluted samples. Samples were then heated and TBARS were quantified by fluorimetric measurement with $515 \mathrm{~nm}$ wavelength excitation and $553 \mathrm{~nm}$ wavelength emission. Malonaldehyde (MDA) was used as standard, and results were expressed in nmol of MDA equivalent/g of proteins.

\section{Statistical analysis}

All data are reported as mean \pm standard deviation and SPSS 13.0 software was used for statistical analysis. Firstly, normal distribution and homoscedasticity of data were verified using KolmogorovSmirnov and Levene tests respectively. Since data sets had not a normal distribution and/or homogeny of variance, the biomarker data was $\log$-transformed, using $\mathrm{F}(\mathrm{x})=\log (1+\mathrm{x})$, prior to parametric analysis. Secondly, a two-way analysis of variance (ANOVA) was performed for each biomarker using sites and gender as factors. When sites by gender interaction was significant $(\alpha=0.05)$, male and female data were treated separately. Biomarker responses measured at each sampling period in uncontaminated mesocosms, were compared using one-way ANOVA followed by Sidak test $(\alpha=0.05)$. To determine the differences between biomarker responses observed in contaminated sites and mesocosms, a t-test was performed $(\alpha=0.05)$. A standardised Principal Component Analysis (PCA) was performed to investigate relationships between investigated variables. A step by step discriminant analysis (DA) using discriminating functions and followed by cross validation was carried out to classify the sites.

\section{RESULTS}

The results for physiological and biochemical parameters are presented in Tables II and III. In these tables, males and females are presented separately when significant differences were revealed by two-way ANOVA performed using site and gender as co-factors for each parameters (Table IV). 


\section{Influence of gender and sampling period on biomarker levels}

Several biotic and abiotic factors are known to affect the biomarker responses. Our results showed that CF, HSI, phase I and phase II biotransformation enzymes, GPx activity and GSH were gender dependent parameters, while TBARS was not (Table IV). No significant interaction was noticed between biomarkers and fish weight or length (data not shown).

In uncontaminated mesocosms, morphological indexes, GPx and TBARS exhibited no significant difference between fish sampled in Spring and in Autumn (Table II and III). In mesocosms, unexpected and relatively high EROD activity was observed in fish sampled during Spring 2003. This measure could be considered as an artefact and is unlikely to be representative of unaffected basal level since comparison to EROD levels in several laboratory controls are generally 5-10 pmol/min/mg (Holm et al., 1993; Sanchez et al., 2005). No other significant differences were noticed for EROD activity measured in mesocosm fish at different sampling periods (Table III). An increase of GST was measured in mesocosm fish sampled in Autumn compared to those sampled in the Spring. Moreover, variations of GSH content were also noticed, with a weaker GSH content in those fish sampled in Spring of 2003 compared to fish in Spring 2004 (Table III).

\section{In situ biomarker responses}

Some morphological index variations were observed between fish from mesocosms and contaminated sites (Table II). CF was increased in female fish sampled in sites OUR, RHO and REV during Spring 2004. HSI was increased in all sites except in LEZ and in male fish from OUR and RHO.

EROD was induced in fish from ESC and in male fish from REV during Spring 2004. A high EROD value was also observed in REV during spring 2003, which corroborates the 2004 results, and indicates that fish were likely to have been exposed to dioxin-like compounds at these sites. A decrease of the EROD activity was measured in female fish from LEZ (Table III). Glutathione S- 
transferase was induced both in males and females from RHO, ESC, and in male fish from REV during Spring 2003, but was inhibited in female fish from OuR and LEZ (Table III).

The assessment of oxidative stress biomarkers showed that antioxidant defences were clearly affected in the sites characterised by moderate or high contamination (i.e. REV, OUR, RHO and ESC) as compared to the low contaminated site LEZ or mesocosms. Depletion of GSH together with increased TBARS levels (up to 4-fold the reference level) showed that pollution-exposed fish were subjected to oxidative stress. Alteration of redox liver status in REV (only in 2003), OUR and RHO, was further confirmed by strong induction of GPx, which is involved in organic and hydro-peroxide degradation.

\section{Multi-variate analysis}

To explore overall relationships between the different variables, we ran a PCA from a matrix data that included biomarkers, morphological and general indexes as variables. The figure $1 \mathrm{~A}$ shows that $58 \%$ of overall variance is explained by the first two principal components. The first principal component (PC1, $42 \%$ of variance) was mainly built by the water quality index (WQI) and TBARS that were found to be strongly correlated ( $r=0.8, p=0.001$, Pearson's coefficient). On this axis, fish from mesocosms and LEZ were clearly distinguished from fish sampled in other sites (not illustrated). The PC2 (16\% of overall variance) was mainly formed by GST and EROD. As expected, this axis distinguished fish from RHO, which had high GST levels, to fish from REV 2004 that had high EROD levels (not illustrated). Moreover, on the first factorial plan of the PCA, different correlation between biomarkers were suggested and further confirmed by Pearson's correlation test : negative correlation between GSH and other oxidative stress parameters : GST $(r=$ -0.238, $\mathrm{p}<0.001)$, GPx $(\mathrm{r}=-0.292, \mathrm{p}<0.001)$ and TBARS $(\mathrm{r}=-0.312, \mathrm{p}<0.001)$, and positive correlation between TBARS and enzymatic antioxidants (GST : r = 0.429, p<0.001 and GPx : r = $0.517, \mathrm{p}<0.001)$ 
We then used step by step DA to further examine the discriminating power of the set of biomarkers. This analysis showed that, while all investigated biomarkers participated significantly to the discrimination, some weighted more heavily than others in site discrimination : TBARS > GST > $\mathrm{EROD}>\mathrm{GSH}>\mathrm{GPx}>\mathrm{HSI}>\mathrm{CF}$. As shown in figure 1B, DA revealed a very good discrimination of the contaminated sites RHO AND ESC with respectively, 100 and $92 \%$ of successful classification rates. The lower rates of successful classification in the contaminated sites REV and OUR were due to the misclassification of some fish in EsC, another impacted site. Likewise, the lower rate in the lesser contaminated site LEZ, were due to badly classified fish in mesocosm groups as they presented low biomarker variations as compared to this group. To overcome variations linked to the sampling period, DA were also performed within each sampling period. Overall, the results confirmed a very good discrimination characterised by successful classification rates, i.e. higher than $75 \%$ for all sites except for the LEZ river where $30 \%$ of fish were badly classified in mesocosm group (data not shown).

\section{Depuration experiment}

In REV, fish exhibited altered levels of all investigated biomarkers as compared to basal levels in mesocosms (Table II and III). The depuration experiment (Table V) demonstrated that to varying degrees, some of the biomarker responses were reversed when fish were moved into clean water for 15 days. CF and HSI slightly decreased by 10 to $30 \%$ in clean water, reaching the level observed in male fish from mesocosms. This was also observed with in situ induction of EROD and GST which were completely reversed after 15 day depuration. In contrast, only slight recoveries were noted for TBARS (decreased by 26\%) and GSH (increased by $34 \%$ in males), while GPx induction was still present after 15 days. Overall, these results confirmed that, in REV, fish had undergone relatively high oxidative damage in the liver that was still persistent after 2 weeks. 


\section{DISCUSSION}

The aim of our research on three-spined stickleback was to determine the potential of this small fish species as a sentinel organism for in situ monitoring of aquatic contaminants. To our knowledge, this study is the first one that has explored the responses of a set of biomarkers in sticklebacks sampled in various contamination contexts. We showed that individual biomarkers such as morphological indexes (CF and HSI), biotransformation enzymes (EROD and GST) and oxidative stress parameters (GPx, GSH and TBARS) were altered in fish sampled in streams impacted by various contaminants and their combination allowed site discrimination.

The need of multi-biomarker approach for freshwater biomonitoring has been largely reported by several previous field studies (Galloway et al., 2004; Triebskorn et al., 2001). In our work, a noteworthy fact was that the set of selected biomarkers was able to discriminate the different sites accordingly to general indexes based on water quality and fish assemblage. Moreover, the biomarker approach enabled to distinguish between two sites that were similarly classified by general indexes. For instance, in the heavily contaminated streams RHO and EsC, biomarker response patterns were different with a strong oxidative stress in RHO compared to ESC where fish exhibited high EROD levels. These differences may probably reflect variation in the nature of chemical contaminants to which the fish were exposed. However, other sites such as OUR and REV were less discriminated than the other impacted sites, e.g. some REV fish were classified in ESC group in the DA. This may reflect a limit in the selected combination of biomarkers and the addition of other specific biomarkers could be a practical way to improve the discriminating power of the battery. Nonetheless, the multivariate analyses showed that the number of investigated biomarkers cannot be reduced without losing discriminating power. This showed that all biomarkers significantly contribute within the battery, although with different weighting.

The biomarker response patterns in stickleback suggested that fish inhabiting in polluted areas may have undergone sublethal stress, possibly due to exposure to different chemical contaminants, 
although chemical analyses in fish could not be performed in this study. EROD activity is a documented biomarker in stickleback and previous laboratory studies investigated its response in this fish species after exposure to polyhalogenated compounds (Holm et al., 1993), pesticides (Sanchez et al., 2006) and metals (Sanchez et al., 2005). In the present study, both basal levels in uncontaminated sites and EROD induction measured in REV and ESC were consistent with the known range of variations for this biomarker in stickleback. The 5-fold observed induction could be considered as moderate as compared to the 20 -fold induction reported by Holm et al. (1993) and probably revealed exposure of fish to aryl hydrocarbon receptor agonists in these sites.

As for EROD, baseline levels of antioxidants and oxidative damages measured in poorly impacted sites were in accordance with the levels previously reported for stickleback (Sanchez et al., 2006; Sanchez et al., 2005). Moreover, both the nature and the extent of oxidative stress biomarker responses observed in fish from contaminated streams (REV, OUR, RHO and ESC) were also in line with the range of variation reported after laboratory exposure to metals (Sanchez et al., 2005) and agricultural technical mixtures (Sanchez et al., 2006). An exception occurred from GPx that was characterised in situ by a strong induction (from 5 to 10 fold as compared to mesocosm fish), which had not been previously observed in laboratory experiments using model oxidative chemicals.

$\mathrm{CF}$ and HSI are general indicators of fish health widely used for population assessments because they integrate many levels of sub-organismal processes and are easily measured. Overall, only minor effects were observed on these parameters as illustrated by their low weight in site discrimination as compared to biochemical parameters in the DA. In stickleback, baseline data are available for comparison (Pottinger et al., 2002; Sokolowska et al., 2004) and show that only HSI of fish from heavily contaminated sites (REV and ESC) is out of the normal range of variation. This result could reflect a liver enlargement in fish exposed to environmental chemicals which corroborated findings from other biochemical biomarkers in these sites. 
Biomarker responses of stickleback appear as a potential relevant tool to assess water quality. The depuration experiment provided valuable information on their reversibility in clean water and their limits for monitoring application. It demonstrated that to varying degrees, biomarker responses were generally reversed when fish were transferred into clean water. Based on this experiment, EROD and GST were characterised by a fast recovery. However, these parameters cannot reflect the time integration of contamination effects, they can only reflect a recent pollution episode. In this context, a frequent sampling could be requested in order to not underestimate pollution (Wu et al., 2005). Conversely, oxidative stress biomarkers such as GPx and TBARS, appeared as parameters characterised by a slow recovery and could be considered as robust biochemical parameters providing a time-integrated estimate of pollution levels. A less frequent sampling is also required to evaluate the effects of water quality on oxidative stress parameters (Wu et al., 2005).

The present work suggested that stickleback biomarker responses were influenced by natural variability. Various biotic factors such as age, gender, feeding behaviour, and environmental factors including diet availability, water temperature, dissolved oxygen level and parasites can enhance or decrease the biotransformation activities (Whyte et al., 2000), antioxidant defences (MartinezAlvarez et al., 2005) and fish health reflected by HSI and CF (Pottinger et al., 2002; Sokolowska et al., 2004). These confounding factors could also prevent using biomarker application for routine monitoring. Hence, it is necessary to characterise natural variability of biomarker responses. This field study provides a first indication on certain confounding factors that could influence the selected biomarkers in stickleback. Except for TBARS, all investigated indicators appeared to be gender-dependent. This effect could be explained by the important variation in physiology and biochemistry of female fish during the reproductive phase as previously described for HSI (Sokolowska et al., 2004) and EROD activity (Flammarion et al., 1998). For instance, some biomarkers such as GST exhibited a seasonal variability with higher levels in Autumn than in Spring. This could be linked to its implication in the hepatic degradation of sex steroids and the 
variation of hormone levels after the breeding period (Gallagher et al., 2001). Interestingly, GPx induction were strongly gender-dependent in OUR and REV sampled in Spring. Similar trends were observed in mesocosms at the same period. To our knowledge, such gender-effect on this enzyme has not been previously reported in fish. In addition, other factors linked to seasonal variability such as predation, parasite infestation and food availability could also be the source of the variation of biomarkers in uncontaminated stickleback (Martinez-Alvarez et al., 2005). As an example, Pascual et al. (2003) showed that susceptibility to oxidative stress in fish, as determined by oxidative stress biomarkers contents, is enhanced by food deprivation. These consideration argue for a better characterisation of stickleback biomarker's natural variability due to biotic and abiotic factors prior to their routine application for freshwater biomonitoring.

\section{CONCLUSION}

This study was designed to assess the usefulness of physiological and biochemical biomarkers in sticklebacks sampled from low and highly impacted areas. The response profiles of investigated biomarkers allowed a good discrimination between highly contaminated streams and moderately polluted or unpolluted sites. Other aspects related to using sticklebacks as a sentinel species were highlighted during this study. The abundance and distribution of stickleback within the study area facilitated sampling of several sites located in reference and polluted areas, however in large rivers, this could be limited by the availability of specific habitats. Moreover, stickleback is characterised by a stationary behaviour, hence the observed responses could reflect the local environment. This field study demonstrates the potential of stickleback as a sentinel fish species to assess sublethal stress in multipollution context. Further studies are in progress to include other specific biomarkers such as vitellogenin, spiggin and cholinesterase in this set of biochemical parameters. In addition, seasonal variability together with chemical analysis of the water will be studied more thoroughly on selected sites in order to better characterise the influence of natural and chemical factors on biomarker responses in this fish species. 


\section{ACKNOWLEDGEMENTS}

We thank the official fishguards from the Conseil Supérieur de la Pêche and S. Lamothe for his technical assistance in fish sampling. We thank also Prof. R. Coulombe (Utah State University) and J. Sabarly for reviewing this manuscript. This work was supported by the French Ministry of Ecology and Sustainable Development (Budget Civil de la Recherche et du Développement AP2004).

\section{REFERENCES}

Bradford MM (1976) A rapid sensitive method for the quantitation of microgram quantities of protein utilizing the principle of protein-dye binding. Anal Biochem 72: 248-254.

EEA (2001) Reporting river quality using the water quality accounts methodology. Application within the Eurowaternet process, Copenhagen, pp. 24.

Flammarion P, Migeon B, Garric J (1998) Statistical analysis of cyprinid ethoxyresorufin-Odeethylase data in a large french watershed. Ecotoxicol Environ Saf 40: 144-153.

Flammarion P, Devaux A, Nehls S, Migeon B, Noury P, Garric J (2002) Multibiomarker responses in fish from the Moselle river (France). Ecotoxicol Environ Saf 51: 145-153.

Gallagher EP, Gross TS, Sheehy KM (2001) Decreased glutathione S-transferase expression and activity and altered sex steroids in Lake Apopka brown bullheads (Ameiurus nebulosus). Aquat Toxicol 55: 223-237.

Galloway TS, Brown RJ, Browne MA, Dissanayake A, Lowe D, Jones MB, Depledge MH (2004) A multibiomarker approach to environmental assessment. Environ Sci Techno 38: 1723-1731.

Habig WH, Pabst MJ, Jakoby WB (1974) Glutathione S-Transferases. The first enzymatic step in mercapturic acid formation. J Biol Chem 249: 7130-7139.

Handy RD, Runnalls T, Russel PM (2002) Histopathologic biomarkers in three spined sticklebacks, Gasterosteus aculeatus, from several rivers in Southern England that meet the freshwater fisheries directive. Ecotoxicology 11: 467-479. 
Holm G, Norrgren L, Andersson T, Thuren A (1993) Effects of exposure to food contaminated with PBDE, PCN or PCB on reproduction, liver morphology and cytochrome P450 activity in the threespined stickleback, Gasterosteus aculeatus. Aquat Toxicol 27: 33-50.

Katsiadaki I, Scott AP, Hurst MR, Matthiessen P, Mayer I (2002) Detection of environmental androgens: a novel method based on enzyme-linked immunosorbent assay of spiggin, the stickleback (Gasterostus aculeatus) glue protein. Environ Toxicol Chem 21: 1946-1954.

Martinez-Alvarez R M, Morales A E, Sanz A (2005) Antioxidant defenses in fish : biotic and abiotic factors. Rev Fish Biol Fisher 15: 75-88.

Oberdorff T, Pont D, Hugueny B, Belliard J, Berrebi Dit Thomas R, Porcher JP (2002) Adaptation et validation d'un indice poisson (FBI) pour l'évaluation de la qualité biologique des cours d'eau français. Bull Fr Pêche Piscic 365/366: 405-433.

Ohkawa H, Ohishi N, Yagi K (1979) Assay for lipid peroxides in animal tissues by thiobarbituric acid reaction. Anal Biochem 95: 351-358.

Paglia DE, Valentine WN (1967) Studies on the quantitative and qualitative characterization of erythrocyte glutathione peroxidase. J Lab Clin Med 70: 158-169.

Pascual P, Pedrajas JR, Toribio F, Lopez-Barea J, Peinado J (2003) Effect of food deprivation on oxidative stress biomarkers in fish (Sparus aurata). Chem-Biol Interact 145: 191-199.

Peakall DW (1994) Biomarkers: the way forward in environmental assessment. Toxicol Ecotoxicol News 1: 55-60.

Pottinger TG, Carrick TR, Yeomans WE (2002) The three-spined stickleback as an environmental sentinel: effects of stressors on whole-body physiological indices. J Fish Biol 61: 207-229.

Sanchez W, Palluel O, Lagadic L, Aït-Aïssa S, Porcher JM (2006) Biochemical effects of nonylphenol polyethoxylate adjuvant, Diquat herbicide and their mixture on the three-spined stickleback (Gasterosteus aculeatus L.). Mar Environ Res 62: S29-S33. 
Sanchez W, Palluel O, Meunier L, Coquery M, Porcher JM, Aït-Aïssa S (2005) Copper-induced oxidative stress in three-spined stickleback: relationship with hepatic metal levels. Environ Toxicol Pharmacol 19: 177-183.

Sokolowska E, Kalamarz H, Kulczykowska E (2004) Seasonal changes in brain melatonin concentration in the three-spined stickleback (Gasterosteus aculeatus): towards an endocrine calendar. Comparative Biochemi Physiol - Part A 139: 365-369.

Strahler AN (1957) Quantitative analysis of watershed geomorphology. Transactions of the American Geophysical Union 38: 913-920.

Sturm A, Wogram J, Segner H, Liess M (2000) Different sensitivity to organophosphates of acetylcholinesterase and butyrylcholinesterase from three-spined stickleback (Gasterosteus aculeatus): application in biomonitoring. Environ Toxicol Chem 19: 1607-1615.

Triebskorn R, Böhmer J, Braunbeck T, Honnen W, Köhler HR, Lehmann R, Oberemm A, Schwaiger J, Segner H, Schüürmann G, Traunspurger W (2001) The project VALIMAR (VALIdation of bioMARkers for the assessment of small stream pollution): objectives, experimental design, summary of results, and recommendations for the application of biomarkers in risk assessment. J Aquat Ecosyst Stress Recov 8: 161-178.

Vandeputte C, Guizon I, Genestie-Denis I, Vannier B, Lorenzon G (1994) A microtiter plate assay for total glutathione and glutathione disulfide contents in cultured/isolated cells: performance study of a new miniaturized protocol. Cell Biol Toxicol 10: 415-421.

Whyte JJ, Jung RE, Schmitt CJ, Tillitt DE (2000) Ethoxyresorufin-O-deethylase (EROD) activity in fish as a biomarker of chemical exposure. Crit Rev Toxicol 30: 347-570.

Wootton RJ (1984) A functional biology of sticklebacks. Croom Helm, London Sidney, 265 pp. Wu RSS, Siu WHL, Shin PKS (2005) Induction, adaptation and recovery of biological responses: Implications for environmental monitoring. Mar Poll Bull 51: 623-634. 
Table I : Summary of some general characteristics of the five selected sites.

\begin{tabular}{|c|c|c|c|c|c|}
\hline & $\begin{array}{l}\text { Réveillon } \\
\text { (REV) }\end{array}$ & $\begin{array}{l}\text { Ourcq } \\
\text { (OuR) }\end{array}$ & $\begin{array}{l}\text { Lézarde } \\
\text { (LEZ) }\end{array}$ & $\begin{array}{c}\text { Rhonelle } \\
\text { (RHO) }\end{array}$ & $\begin{array}{l}\text { Escaut } \\
\text { (ESC) }\end{array}$ \\
\hline \multirow{2}{*}{ GPS coordinates } & N 4843'00’' & N 4911'42”' & N 49³4'09" & N 50॰17’49”' & N 532' $40^{\prime \prime}$ \\
\hline & Е $2^{\circ} 32^{\prime} 09^{\prime \prime}$ & E $3^{\circ} 31^{\prime} 32^{\prime \prime}$ & E $0^{\circ} 13^{\prime} 20^{\prime \prime}$ & E $3^{\circ} 32^{\prime} 41^{\prime \prime}$ & E $3^{\circ} 32^{\prime} 56^{\prime \prime}$ \\
\hline Strahler's rank ${ }^{a}$ & 2 & 3 & 1 & 2 & 4 \\
\hline Pressure $^{b}$ & Urban dense & $\begin{array}{l}\text { Intensive } \\
\text { agriculture }\end{array}$ & Mixed & Urban dense & Urban dense \\
\hline Water quality ${ }^{c}$ & - & Medium & Good & Bad & Bad \\
\hline Fish based index ${ }^{d}$ & 5 & 4 & 3 & 3 & 3 \\
\hline Sampling period & $\begin{array}{l}\text { Spring } 2003 \\
\text { Spring } 2004\end{array}$ & Spring 2003 & $\begin{array}{l}\text { Autumn } \\
2004\end{array}$ & $\begin{array}{l}\text { Autumn } \\
2004\end{array}$ & $\begin{array}{c}\text { Autumn } \\
2004\end{array}$ \\
\hline
\end{tabular}

${ }^{a}$ Strahler's rank based on structure and density of hydrographic network (Strahler, 1957).

${ }^{b}$ Data obtained from the Eurowaterne database of European Environment Agency (EEA, 2001).

" Data obtained from the "Seine-Normandie" water agency for OUR and LEZ and from "ArtoisPicardie" water agency for RHO and EsC.

${ }^{\mathrm{d}}$ Fish based-index quality score based on occurrence and abundance data and reflecting the level of degration of fish assemblage structure (Oberdorff et al., 2002). FBI score ranged from 1 (no disturbance) to 5 (very high disturbance). 
Table II : Morphological parameters for three-spined sticklebacks sampled in contaminated sites and uncontaminated mesocosms. Data are presented as mean \pm SD. * indicates a significant difference compared to mesocosm group sampled at the same period $(p<0.05)$. Mesocosm groups annotated with different letters are significantly different $(p<0.05)$.

\begin{tabular}{|c|c|c|c|c|c|c|c|}
\hline $\begin{array}{l}\text { Sampling } \\
\text { period }\end{array}$ & Sites & Gender & $\begin{array}{c}\text { Fish } \\
\text { number }\end{array}$ & $\begin{array}{l}\text { Fish length } \\
(\mathrm{mm})\end{array}$ & $\begin{array}{c}\text { Fish weight } \\
(\mathrm{g})\end{array}$ & $\mathrm{CF}$ & $\begin{array}{c}\text { HSI } \\
\% \\
\end{array}$ \\
\hline \multirow{6}{*}{$\begin{array}{l}\text { Spring } \\
2003\end{array}$} & \multirow{2}{*}{ MEso } & $\hat{0}$ & 11 & $43 \pm 3^{A}$ & $0.7 \pm 0.3^{\mathrm{A}}$ & $0.9 \pm 0.2^{\mathrm{A}}$ & $2.3 \pm 1.8^{\mathrm{A}}$ \\
\hline & & q & 19 & $44 \pm 4^{\mathrm{A}}$ & $0.8 \pm 0.2^{\mathrm{A}}$ & $1.0 \pm 0.2^{\mathrm{A}}$ & $3.3 \pm 1.1^{\mathrm{A}}$ \\
\hline & \multirow{2}{*}{ REV } & $\lambda$ & 14 & $54 \pm 3 *$ & $1.6 \pm 0.3^{*}$ & $1.0 \pm 0.1$ & $4.1 \pm 1.3^{*}$ \\
\hline & & ㅇ & 15 & $54 \pm 4 *$ & $1.6 \pm 0.4^{*}$ & $1.0 \pm 0.1$ & $6.1 \pm 0.9 *$ \\
\hline & \multirow{2}{*}{ OUR } & $\hat{0}$ & 9 & $54 \pm 3 *$ & $1.7 \pm 0.3^{*}$ & $1.0 \pm 0.1$ & $3.1 \pm 0.7$ \\
\hline & & q & 4 & $55 \pm 4^{*}$ & $1.9 \pm 0.2^{*}$ & $1.2 \pm 0.1^{*}$ & $7.2 \pm 1.2^{*}$ \\
\hline \multirow{4}{*}{$\begin{array}{l}\text { Spring } \\
2004\end{array}$} & \multirow{2}{*}{ MEso } & 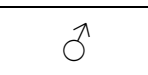 & 14 & $50 \pm 7^{B}$ & $4.3 \pm 0.5^{\mathrm{AB}}$ & $1.0 \pm 0.1^{\mathrm{A}}$ & $1.7 \pm 0.6^{\mathrm{A}}$ \\
\hline & & $q$ & 10 & $59 \pm 6^{B}$ & $2.0 \pm 0.7^{\mathrm{B}}$ & $1.0 \pm 0.2^{\mathrm{A}}$ & $2.5 \pm 0.7^{\mathrm{A}}$ \\
\hline & \multirow{2}{*}{ REV } & $\hat{O}$ & 15 & $57 \pm 4 *$ & $2.0 \pm 0.4^{*}$ & $1.0 \pm 0.09$ & $3.5 \pm 0.7 *$ \\
\hline & & q & 15 & $58 \pm 4$ & $2.4 \pm 0.6$ & $1.2 \pm 0.1 *$ & $8.2 \pm 1.0^{*}$ \\
\hline \multirow{8}{*}{$\begin{array}{l}\text { Autumn } \\
2004\end{array}$} & \multirow{2}{*}{ MESO } & 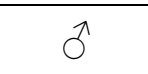 & 15 & $53 \pm 4^{\mathrm{B}}$ & $1.4 \pm 0.4^{\mathrm{B}}$ & $0.9 \pm 0.1^{\mathrm{A}}$ & $2.4 \pm 0.8^{\mathrm{A}}$ \\
\hline & & $q$ & 15 & $52 \pm 7^{\mathrm{C}}$ & $1.3 \pm 0.7^{\mathrm{A}}$ & $0.9 \pm 0.1^{\mathrm{A}}$ & $2.7 \pm 0.4^{\mathrm{A}}$ \\
\hline & \multirow{2}{*}{ LEZ } & $\hat{O}$ & 10 & $39 \pm 3 *$ & $0.6 \pm 0.1^{*}$ & $1.0 \pm 0.08$ & $2.4 \pm 0.6$ \\
\hline & & q & 18 & $39 \pm 1 *$ & $0.6 \pm 0.1^{*}$ & $0.9 \pm 0.06$ & $2.4 \pm 0.7$ \\
\hline & \multirow{2}{*}{ RHO } & $\hat{\jmath}$ & 13 & $59 \pm 3 *$ & $2.1 \pm 0.4^{*}$ & $1.0 \pm 0.09$ & $3.0 \pm 0.8$ \\
\hline & & q & 17 & $59 \pm 5^{*}$ & $2.1 \pm 0.5^{*}$ & $1.0 \pm 0.08 *$ & $5.0 \pm 1.1^{*}$ \\
\hline & \multirow{2}{*}{ EsC } & $\hat{O}$ & 19 & $51 \pm 3$ & $1.3 \pm 0.2$ & $1.0 \pm 0.06$ & $4.1 \pm 1.4^{*}$ \\
\hline & & q & 8 & $50 \pm 4$ & $1.3 \pm 0.3$ & $1.0 \pm 0.07$ & $3.3 \pm 0.6^{*}$ \\
\hline
\end{tabular}


Table III : Biomarker responses for three-spined sticklebacks sampled in contaminated sites and uncontaminated mesocosms. Data are presented as mean $\pm \mathrm{SD} . *$ indicates a significant difference compared to mesocosm group sampled at the same period $(p<0.05)$. Mesocosm groups annotated with different letters are significantly different $(p<0.05)$.

\begin{tabular}{|c|c|c|c|c|c|c|c|c|}
\hline $\begin{array}{l}\text { Sampling } \\
\text { period }\end{array}$ & Sites & Gender & $\begin{array}{c}\text { Fish } \\
\text { number }\end{array}$ & $\begin{array}{c}\text { EROD } \\
\mathrm{pmol} / \mathrm{min} / \mathrm{mg}\end{array}$ & $\begin{array}{c}\text { GST } \\
\mathrm{U} / \mathrm{g} \\
\end{array}$ & $\begin{array}{l}\text { GPx } \\
\text { U/g }\end{array}$ & $\begin{array}{c}\mathrm{GSH} \\
\mu \mathrm{mol} / \mathrm{g} \\
\end{array}$ & $\begin{array}{l}\text { TBARS } \\
\mathrm{nmol} / \mathrm{g}\end{array}$ \\
\hline \multirow{6}{*}{$\begin{array}{l}\text { Spring } \\
2003\end{array}$} & \multirow{2}{*}{ MEso } & $\widehat{0}$ & 11 & $23.9 \pm 19.8^{\mathrm{A}}$ & $1273 \pm 406^{\mathrm{A}}$ & $57 \pm 14^{\mathrm{A}}$ & $41.6 \pm 25.0^{\mathrm{A}}$ & \multirow{2}{*}{$46 \pm 25^{\mathrm{A}}$} \\
\hline & & q & 19 & $32.1 \pm 27.2^{\mathrm{A}}$ & $1233 \pm 417^{\mathrm{A}}$ & $113 \pm 57^{\mathrm{A}}$ & $23.9 \pm 18.4^{\mathrm{A}}$ & \\
\hline & \multirow{2}{*}{ REV } & $\hat{0}$ & 14 & $34.1 \pm 15.7$ & $2131 \pm 538^{*}$ & $88 \pm 29 *$ & $18.1 \pm 1.3^{*}$ & \multirow{2}{*}{$148 \pm 41 *$} \\
\hline & & $q$ & 15 & $20.3 \pm 9.6$ & $1304 \pm 881$ & $583 \pm 211^{*}$ & $20.4 \pm 5.9$ & \\
\hline & \multirow{2}{*}{ OUR } & $\widehat{O}$ & 9 & $7.9 \pm 3.9^{*}$ & $1458 \pm 539$ & $60 \pm 25$ & $23.5 \pm 6.0^{*}$ & \multirow{2}{*}{$92 \pm 21 *$} \\
\hline & & q & 4 & $9.7 \pm 4.7 *$ & $688 \pm 147^{*}$ & $809 \pm 72 *$ & $18.4 \pm 1.8$ & \\
\hline \multirow{4}{*}{$\begin{array}{l}\text { Spring } \\
2004\end{array}$} & \multirow{2}{*}{ MEso } & 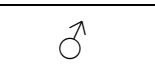 & 14 & $4.9 \pm 1.8^{\mathrm{B}}$ & $1259 \pm 522^{\mathrm{A}}$ & $74 \pm 47^{\mathrm{A}}$ & $59.7 \pm 6.5^{\mathrm{A}}$ & \multirow{2}{*}{$53 \pm 29^{\mathrm{A}}$} \\
\hline & & q & 10 & $8.4 \pm 4.3^{\mathrm{B}}$ & $1486 \pm 779^{\mathrm{A}}$ & $134 \pm 116^{\mathrm{A}}$ & $82.7 \pm 74.6^{\mathrm{B}}$ & \\
\hline & \multirow{2}{*}{ REV } & $\hat{0}$ & 15 & $43.3 \pm 35.9 *$ & $1063 \pm 514$ & $72 \pm 46$ & $42.8 \pm 19.7 *$ & \multirow{2}{*}{$164 \pm 46^{*}$} \\
\hline & & q & 15 & $22.7 \pm 33.8$ & $1195 \pm 1226$ & $72 \pm 57$ & $47.8 \pm 17.3$ & \\
\hline \multirow{8}{*}{$\begin{array}{l}\text { Autumn } \\
2004\end{array}$} & \multirow{2}{*}{ MESO } & 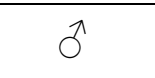 & 15 & $4.5 \pm 2.1^{\mathrm{B}}$ & $1843 \pm 419^{\mathrm{B}}$ & $119 \pm 113^{\mathrm{A}}$ & $36.1 \pm 15.5^{\mathrm{A}}$ & \multirow{2}{*}{$55 \pm 17^{\mathrm{A}}$} \\
\hline & & q & 15 & $5.0 \pm 4.0^{\mathrm{B}}$ & $2105 \pm 479^{\mathrm{B}}$ & $134 \pm 53^{\mathrm{A}}$ & $46.5 \pm 18.9^{\mathrm{B}}$ & \\
\hline & \multirow{2}{*}{ LEZ } & $\hat{0}$ & 10 & $4.6 \pm 3.6$ & $1572 \pm 385$ & $160 \pm 68$ & $42.2 \pm 10.1$ & \multirow{2}{*}{$48 \pm 14$} \\
\hline & & $q$ & 18 & $2.6 \pm 1.7^{*}$ & $1151 \pm 362^{*}$ & $118 \pm 69$ & $41.8 \pm 21.2$ & \\
\hline & \multirow{2}{*}{ RHO } & $\widehat{0}$ & 13 & $3.2 \pm 1.4$ & $3638 \pm 601 *$ & $440 \pm 136^{*}$ & $13.6 \pm 3.3^{*}$ & \multirow{2}{*}{$203 \pm 33^{*}$} \\
\hline & & o & 17 & $4.1 \pm 3.6$ & $3457 \pm 636^{*}$ & $564 \pm 127^{*}$ & $14.0 \pm 4.8^{*}$ & \\
\hline & \multirow{2}{*}{ EsC } & $\hat{O}$ & 19 & $22.5 \pm 5.7 *$ & $2778 \pm 675^{*}$ & $84 \pm 37$ & $24.6 \pm 7.0$ & \multirow{2}{*}{$127 \pm 25^{*}$} \\
\hline & & q & 8 & $27.6 \pm 7.7^{*}$ & $2782 \pm 190 *$ & $136 \pm 40$ & $25.4 \pm 5.1^{*}$ & \\
\hline
\end{tabular}


Table IV : Results of two-way ANOVA performed for physiological parameters and biochemical biomarkers in three-spined stickleback sampled in all study sites. * indicates that null hypothesis is not assumed $(p<0.05)$.

\begin{tabular}{lccc}
\hline Biomarkers & $\begin{array}{c}\text { Sites } \\
(p)\end{array}$ & $\begin{array}{c}\text { Gender } \\
(p)\end{array}$ & $\begin{array}{c}\text { Interaction } \\
(p)\end{array}$ \\
\hline Fish length & $<0.001^{*}$ & $<0.001^{*}$ & 0.143 \\
\hline Fish weight & $<0.001^{*}$ & $<0.001^{*}$ & 0.084 \\
\hline CF & $<0.001^{*}$ & 0.337 & $0.039^{*}$ \\
HSI & $<0.001^{*}$ & $<0.001^{*}$ & $<0.001^{*}$ \\
EROD & $<0.001^{*}$ & $0.364^{*}$ & $0.037^{*}$ \\
GST & $<0.001^{*}$ & $0.024^{*}$ & $0.015^{*}$ \\
GPx & $<0.001^{*}$ & $<0.001^{*}$ & $<0.001^{*}$ \\
GSH & $<0.001^{*}$ & 0.756 & $0.009^{*}$ \\
TBARS & $<0.001^{*}$ & 0.549 & 0.355 \\
\hline
\end{tabular}


Table V. Biomarker responses in fish from REV maintained 15 days in clean water. The unit of each biomarker is indicated in the Table III and IV. Data are presented as mean \pm SD. * indicates a significant difference compared to $\mathrm{t}_{0}$ control group $(p<0.05) .{ }^{\mathrm{a}}$ indicates $\mathrm{n}=1$.

\begin{tabular}{|c|c|c|c|c|c|}
\hline & & \multicolumn{4}{|c|}{ Days of depuration } \\
\hline & & 0 & 4 & 8 & 15 \\
\hline \multirow{2}{*}{$\begin{array}{c}\text { Fish } \\
\text { number }\end{array}$} & 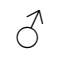 & 14 & 9 & 12 & 12 \\
\hline & q & 15 & 6 & 3 & 3 \\
\hline \multirow{2}{*}{$\mathrm{CF}$} & $\hat{0}$ & $1.0 \pm 0.1$ & $1.0 \pm 0.1$ & $0.9 \pm 0.09^{*}$ & $0.9 \pm 0.07^{*}$ \\
\hline & $q$ & $1.0 \pm 0.1$ & $1.0 \pm 0.1$ & $0.8 \pm 0.07 *$ & $0.9 \pm 0.03 *$ \\
\hline \multirow{2}{*}{ HSI } & $\hat{\sigma}$ & $4.1 \pm 1.3$ & $2.8 \pm 0.6^{*}$ & $2.6 \pm 0.5^{*}$ & $2.7 \pm 0.9 *$ \\
\hline & q & $6.1 \pm 0.9$ & $4.9 \pm 0.9 *$ & $3.9 \pm 0.05^{*}$ & $4.8 \pm 0.5^{*}$ \\
\hline \multirow{2}{*}{ EROD } & 0 & $34.1 \pm 15.7$ & $14.2 \pm 9.3^{*}$ & $23.4 \pm 20.9$ & $5.5 \pm 4.3^{*}$ \\
\hline & q & $20.3 \pm 9.6$ & $8.3 \pm 5.4^{*}$ & $4.4 \pm 2.5^{*}$ & $4.1 \pm 4.9 *$ \\
\hline \multirow{2}{*}{ GST } & $\hat{o}$ & $2131 \pm 538$ & $1818 \pm 637$ & $1393 \pm 412^{*}$ & $1250 \pm 461 *$ \\
\hline & q & $1304 \pm 881$ & $1246 \pm 518$ & $1461 \pm 635$ & $1284 \pm 502$ \\
\hline \multirow{2}{*}{ GPx } & $\hat{0}$ & $88 \pm 29$ & $98 \pm 28$ & $37.2 \pm 18.0^{*}$ & $68 \pm 88$ \\
\hline & q & $583 \pm 211$ & $533 \pm 294$ & $689^{a}$ & $588 \pm 104$ \\
\hline \multirow{2}{*}{ GSH } & $0^{\pi}$ & $18.1 \pm 1.3$ & $23.2 \pm 5.1^{*}$ & $19.1 \pm 11.2$ & $24.2 \pm 6.0^{*}$ \\
\hline & q & $20.4 \pm 5.9$ & $17.5 \pm 5.5$ & $24 \pm 13.7$ & $17.8 \pm 0.8$ \\
\hline TBARS & & $148 \pm 41$ & $147 \pm 37$ & $127 \pm 29$ & $109 \pm 21 *$ \\
\hline
\end{tabular}


Figure 1. Multivariate analysis carried out all data including the nine sites as samples and 7 biomarkers as variables. A : Representation of the biomarkers and the environmental variables (WQI and FBI) in the first factorial plane of the PCA. B : Discriminant analysis (DA) presenting the stream separation based on biomarker responses. For each location, the rate of successful classification is presented in brackets. 
A

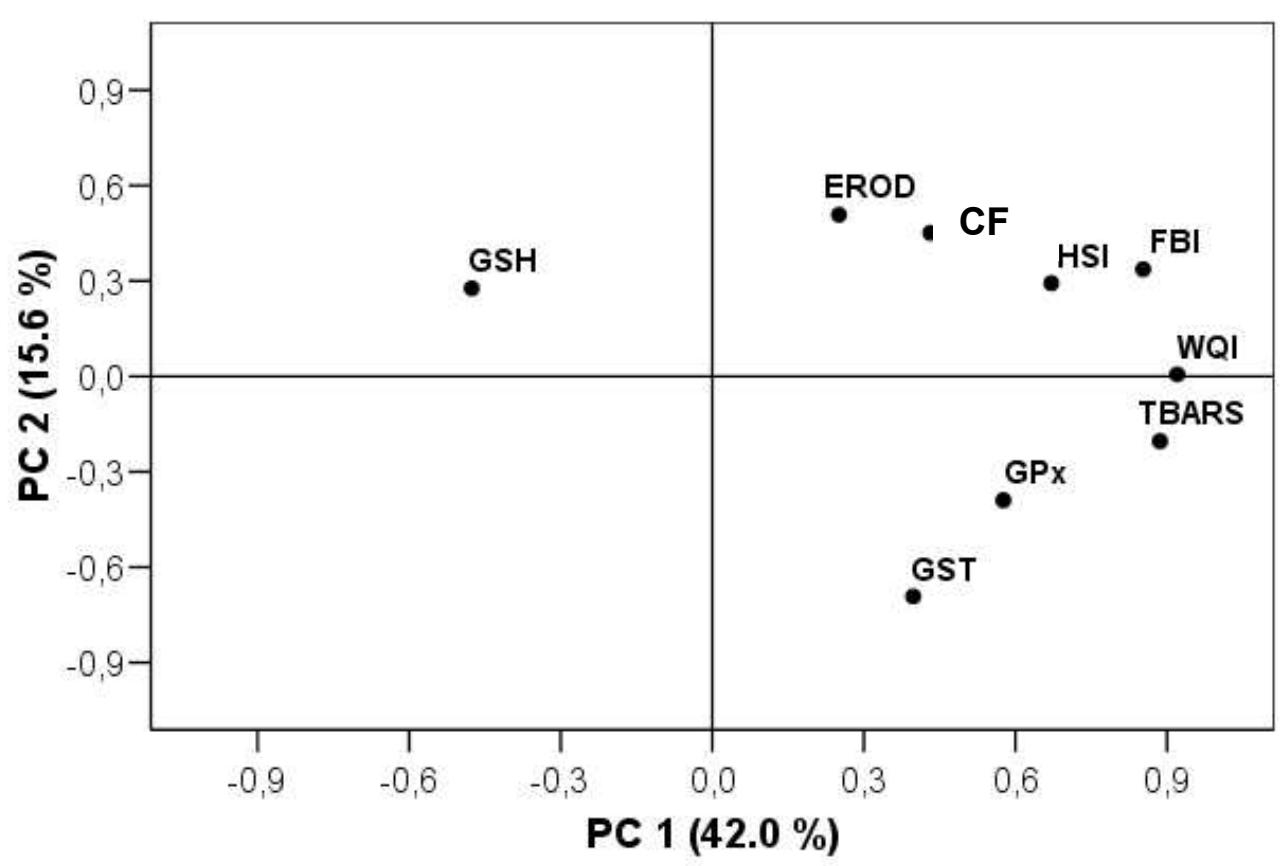

B

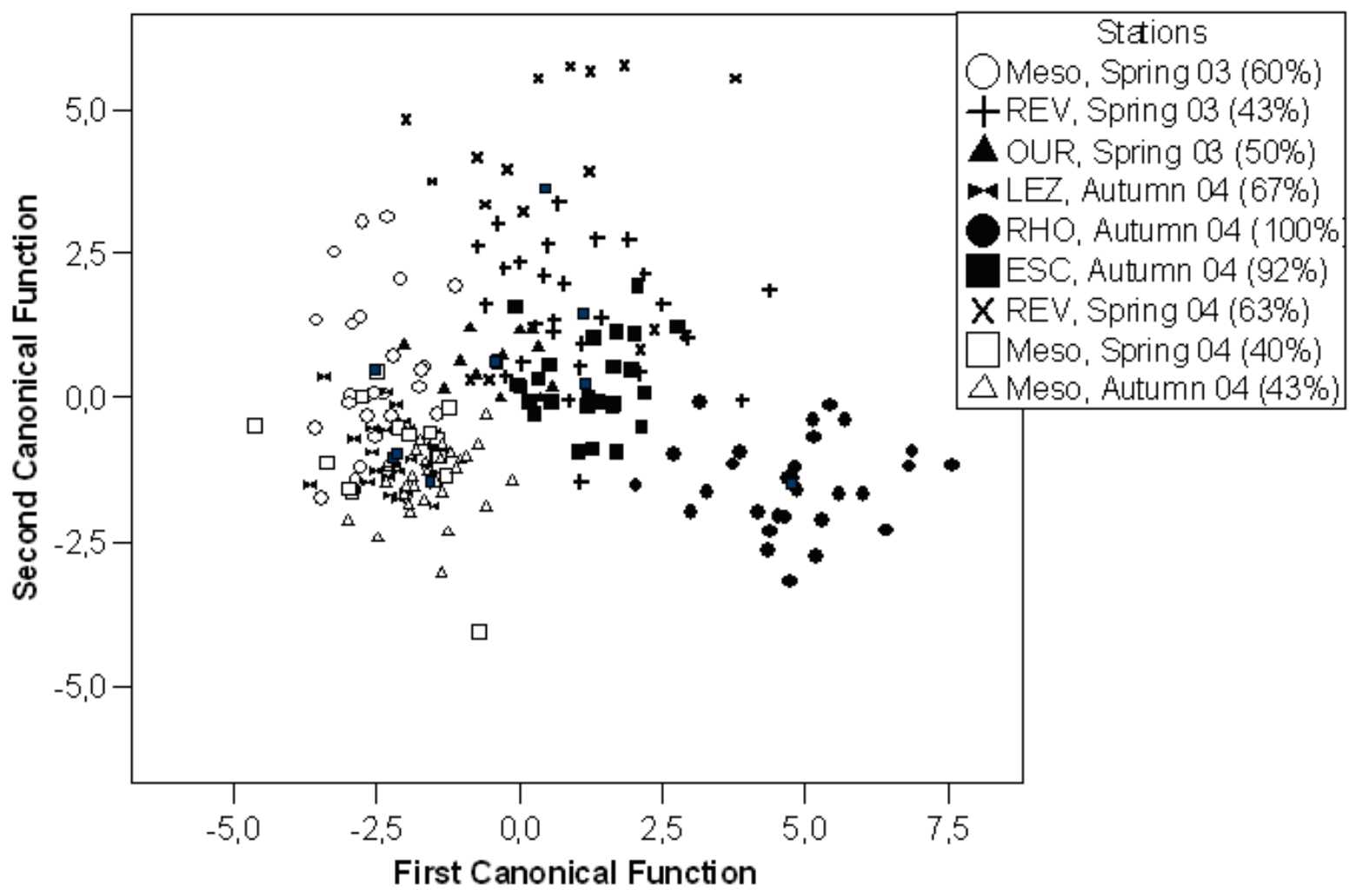

Figure 1. 